\title{
Nutritional Traits of Silage Produced from Alfalfa (Medicago sativa L.) Cultivated Using Conventional Technology versus Organic Technology in Support of Higher Dairy Productions
}

\author{
Ioan Zamfir MARCHIȘ ${ }^{1}$, Daniela LADOȘI ${ }^{1}$, Camelia OROIAN ${ }^{2 *}$, Antonia \\ ODAGIU $^{3}$, Vasile IUGA ${ }^{3}$, Simona PAȘCALĂU ${ }^{1}$, Aurelia COROIAN ${ }^{1}$
}

\author{
${ }^{1}$ University of Agricultural Sciences and Veterinary Medicine Cluj-Napoca, Faculty of Animal Husbandry and Biotechnology, 3-5 Calea \\ Mănăstur,400372Cluj-Napoca,Romania; zamfir.marchis@usamvcluj.ro;iuga.vasile@gmail.com; coroian.aurelia@usamvcluj.ro; \\ pascalau.simona@usamvcluj.ro; ladosi.daniela@usamvcluj.ro \\ ${ }^{2}$ University of Agricultural Sciences and Veterinary Medicine Cluj-Napoca, Faculty of Horticulture, 3-5 Calea Mănăștur, 400372 Cluj-Napoca, \\ Romania; camelia.oroian@usamvcluj.ro (*correspondingauthor) \\ ${ }^{3}$ University of Agricultural Sciences and Veterinary Medicine Cluj-Napoca, Faculty of Agriculture, 3-5 Calea Mănăștur, 400372 Cluj-Napoca, \\ Romania; antonia.odagiu@usamvcluj.ro
}

\begin{abstract}
As consequence of increasing need of higher livestock productions, in conditions of assuring environmental sustainability, comparative tests of properties of forages obtained by application of conventional technologies compared with those obtained as result of organic practices, may be useful. Thus our trial covers issues concerning comparative study of nutritional traits, expresses through chemical composition indices, of silage obtained from alfalfa resulted from two types of cultivation technologies, conventional, and organic, respectively. The experiment was carried out in a familiar farm located near Huedin, County of Cluj, Romania. Higher contents of dry matter, acid detergent fibre, and ammonia are reported in silage obtained from alfalfa cultivated in organic technology, compared to silage obtained from alfalfa conventionally produced. The ammonia content of silage obtained from alfalfa cultivated using conventional technology, reported as \% from dry matter, is the single chemical index where high diversity within individual values was identified. Correlations of similar intensities were identified between the indices of the chemical composition of the silage obtained from both, conventionally and organic, cultivated alfalfa. The alfalfa cultivated in organic system promotes higher amounts of crude protein, neutral detergent fibre, and total volatile fatty acids, in alfalfa silage.
\end{abstract}

Keywords: alfalfa; chemical composition; feed, livestock; nutritional traits

\section{Introduction}

An important challenge of our times is assuring the sustainability of cultures. In this respect adopting practices in harmony with natural environment and practicing organic agriculture wherever possible became more and more an achievable desiderate. These practices bring benefits not only to biodiversity, but also to the environment and human health (Hole et al., 2005; Jenkins and McGuire, 2006; Norton et al., 2009; Verbruggen et al., 2010; Wood et al., 2000).

The present global realities impose focusing the organic production, and this affects also the forage production destined to livestock maintaining mainly in middle sized or small familial farms. A series of leguminous plants destined to livestock feeding, fresh, as hay or silage, begun to be cultivated using organic technologies (Larsen et al., 2010; Stiglbauer et al., 2013).

Alfalfa (Medicago sativa $\mathrm{L}$.) is largely used worldwide as feed resource for livestock. It may be used fresh, but also as hay and/or silage. The silage solution is more suitable in areas where the harvesting period is characterized by wet climate, with high rainfall quantities. Because the alfalfa content in dry matter is an important element of production, the preservation of this parameter at high values is one of the most important desiderate of the alfalfa production. In this respect, we have to mention that ensiling process plays an important role. If inoculants are added to the alfalfa during ensiling process, the most important traits 
436

of the nutritional composition (e.g. dry matter, crude protein) are preserved. In organic production systems, inoculants are also used, but they are produced by specialized companies (Basset-Mens et al., 2009; Dewhurst et al., 2003; Hristov et al, 2002; Hristov et al.).

Our trial aims to emphasize the values of the nutritional traits of the alfalfa silages, expressed through their chemical composition indices, function of technology of alfalfa production (organic and conventional), and also the interaction between the silage chemical composition indices, function of the alfalfa production methodology.

\section{Materials and Methods}

\section{Study site}

The research was carried out in a middle size private family farm located in the County of Cluj, Romania, in the vicinity of the Huedin town $\left(46^{\circ} 52^{\prime} 00^{\prime \prime} \mathrm{N}\right.$, and $\left.23^{\circ} 02^{\prime} 00^{\prime \prime} \mathrm{E}\right)$, where alfalfa is cultivated, and where alfalfa silage is produced, in order to be used as feed administered to the dairy cows, also reared in the farm.

\section{Biological material and experimental design}

The 'Roxana' variety of alfalfa was used. Two groups were organized. One group was made of silage resulted from ensiling alfalfa cultivated using conventional technology (control), and other group (experimental), resulted from ensiling alfalfa cultivated using organic technology.

\section{Qualitative analysis}

The alfalfa silage $\mathrm{pH}$, dry matter (\%), and chemical composition of the alfalfa silage expressed as \% of dry matter (crude protein, crude ash, neutral detergent fibre, acid detergent fibre, total volatile fatty acids, and ammonia) were determined in the Environmental Quality Control Laboratory and Plant Protection from UASVM ClujNapoca, according to AOAC methodology (2005).

\section{Statistical procedures}

Statistical processing was carried out SPSS Statistics v. 20. In order to characterize the nutritional traits of the alfalfa silages, and emphasize the differences between them from the point of view of statistical significance, the descriptive statistics tools were implemented. The Pearson coefficients of correlations were calculated in order to reveal the interrelations established between nutritional components of the alfalfa silages obtained using both, conventional and organic technologies. The factorial analysis through Principal Components Analysis (PCA) was used in order to emphasize the influence of the above mentioned variables upon the outputs of the cultivation technology.

\section{Results and Discussion}

The nutritional content of alfalfa silage resulted from both groups; alfalfa cultivated using organic and conventional technologies, differs significantly and highly significantly, if referring to certain compounds. Thus, organic alfalfa silage recorded a higher dry matter, acid detergent fibre, and ammonia content, compared to conventional alfalfa silage, statistically assured at significance threshold of $5 \%$, while $\mathrm{pH}$ is highly significantly higher $(p<0.01)$ in organic alfalfa silage (Table 1$)$. The dispersion parameters indicate a normal distribution of data, while variability shows a good homogeneity of the sample and representativeness of the mean (Table 1 ).

In terms of dry matter content and crude protein content of alfalfa silage, whatever obtaining methodology, our results are similar with those obtained by Leduc et al. (2017), but they differ, in NDF content, which is twice higher in our samples. Taking into account that we use the same NDF determination methodology as cited authors, the reason may be the alfalfa variety used in our trial.

Table 1. The basic statistics and significance of differences for crude composition of silage obtained from alfalfa cultivated using organic (experimental) and conventional (control) technologies, \% from DM

\begin{tabular}{|c|c|c|c|c|c|c|c|c|}
\hline \multirow{2}{*}{ Trait } & \multicolumn{8}{|c|}{ Parameter } \\
\hline & $\mathrm{N}$ & $\mathrm{X}$ & $s$ & $s x$ & Min & Max & $\mathrm{CV}$ & $\mathrm{p}$ \\
\hline \multicolumn{9}{|c|}{ Alfalfa silage - experimental } \\
\hline DM, \% & 25 & 47.80 & 1.29 & 0.12 & 46.80 & 49.90 & 2.71 & $0.017^{*}$ \\
\hline $\mathrm{CP}, \%$ & 25 & 18.58 & 0.48 & 0.04 & 18.00 & 19.10 & 2.59 & $0.211^{\mathrm{ns}}$ \\
\hline $\mathrm{CA}, \%$ & 25 & 8.30 & 0.16 & 0.01 & 8.10 & 8.50 & 1.90 & $0.199^{\mathrm{ns}}$ \\
\hline $\mathrm{ADF}, \%$ & 25 & 26.90 & 1.44 & 0.13 & 25.40 & 28.50 & 5.35 & $0.027^{*}$ \\
\hline NDF, $\%$ & 25 & 46.58 & 1.32 & 0.12 & 45.10 & 48.40 & 2.84 & $0.070^{\mathrm{ns}}$ \\
\hline TVFA, $\%$ & 25 & 2.12 & 0.24 & 0.02 & 1.80 & 2.40 & 11.26 & $0.634^{\mathrm{ns}}$ \\
\hline $\mathrm{pH}$ & 25 & 5.52 & 0.26 & 0.02 & 5.20 & 5.90 & 4.69 & $0.002^{*}$ \\
\hline $\mathrm{NH}_{3}, \%$ & 25 & 12.53 & 1.12 & 0.10 & 10.94 & 13.90 & 8.95 & $0.018^{*}$ \\
\hline \multicolumn{9}{|c|}{ Alfalfa silage - control } \\
\hline DM, \% & 25 & 38.68 & 4.22 & 0.38 & 34.00 & 45.10 & 10.90 & - \\
\hline СР, \% & 25 & 17.78 & 1.23 & 0.11 & 16.30 & 19.50 & 6.90 & - \\
\hline CA,\% & 25 & 8.60 & 0.45 & 0.04 & 8.10 & 9.10 & 5.26 & \\
\hline ADF, \% & 25 & 24.25 & 1.67 & 0.33 & 22.00 & 26.00 & 6.89 & - \\
\hline NDF, \% & 25 & 44.06 & 1.60 & 0.14 & 42.00 & 46.00 & 3.63 & - \\
\hline TVFA, \% & 25 & 2.04 & 0.27 & 0.02 & 1.60 & 2.30 & 13.24 & - \\
\hline $\mathrm{pH}$ & 25 & 4.90 & 0.19 & 0.02 & 4.60 & 5.10 & 3.82 & - \\
\hline $\mathrm{NH}_{3}, \%$ & 25 & 10.56 & 0.96 & 0.09 & 9.80 & 12.20 & 9.12 & - \\
\hline
\end{tabular}

$\mathrm{N}$ - number of cases; X - Mean; $s$ - Standard deviation; sx - Standard error of mean; CV - Coefficient of variation; Min - Minimum value; Max - Maximum value; $\mathrm{p}$ probability, ns - No significant, $\mathrm{p}>0.05 ;^{*}$ - Significant at $\mathrm{p}<0.05 ;{ }^{* *}$ - Highly significant at $\mathrm{p}<0.05$. DM - Dry Matter; CP - Crude Protein; CA - Crude Ash; ADF Acid Detergent Fibre; NDF - Neutral Detergent Fibre; TVFA - Total Volatile Fatty Acids; $\mathrm{NH}_{3}$ - Ammonium. 
Very weak to strong Pearson's correlations are reported between conventional cultivated alfalfa silage nutritional content, when intensity of correlations is tested in control group. The strongest correlations are reported between crude protein, dry matter and neutral detergent fibre, respectively, and they are positive. The $\mathrm{pH}$ of the alfalfa silage, in control group, is negatively, and weak correlated with majority of the parameters describing the chemical composition of the alfalfa silage, except acid detergent fibre to which is positively moderate correlated, total volatile fatty acids and ammonia contents, to which is positively, but weak correlated (Table 2). Urea is also negatively correlated with the largest majority of the alfalfa silage chemical components, except the content of total volatile fatty acids (Table 2).

Similarly with interactions identified in control group, very weak to strong Pearson's correlations are reported between chemical compositions items analysed in organic alfalfa silage, considered as experimental group. In this case, also very strong positive correlations are reported, between crude protein, dry matter and neutral detergent fibre (Table 3). The $\mathrm{pH}$ of the alfalfa silage, is positively, and weak correlated only with acid detergent fiber, total volatile fatty acids and ammonia contents, to which is positively, but weak correlated (Table 3). The same urea is negatively correlated with the largest majority of the organic alfalfa silage chemical components (Table 3).

The correlation identified between chemical components describing the nutritional value of both control and experimental groups (Tables 2 and 3) allow us to develop the PCA, in order to identify the importance of the principal nutritional traits of the alfalfa silages, expressed through their chemical composition, when conventional and organic alfalfa cultivation systems are used. This approach is consistent with others practiced in order classify forages, and predict their nutritional value in livestock feeding (Gallo et al., 2013).

Applying the Principal Components Analysis (PCA) technique of the multivariate analysis, two principal components are identified, conventional, and organic culture systems, respectively. They describe a quality of representation of $70.126 \%$, and cumulative Eigenvalues correspondent to the value of 11.22, as emphasized in Table 4. The factor 1 - organic culture explains $37.42 \%$ of variance, correspondent to 5.988 variables, while factor 2 conventional culture explains $32.69 \%$ of variance, correspondent to 5.231 variables.

According to factor loadings (Fig. 1), and correlations emphasized between them (Table 5), organic culture promotes the increase of crude protein, neutral detergent fibre, and total volatile fatty acids, while crude fat and ammonia increase in silage, is promoted only in conditions of conventional technology of alfalfa culture.

Our study emphasizes that silage obtained from alfalfa cultivated in organic technology have higher quantities of dry matter, acid detergent fibre, and ammonia content, compared to silage obtained from alfalfa resulted from application of conventional production technologies. The differences were assured at significance thresholds of 5\%, and $1 \%$, respectively.

Table 2. The Pearson's coefficients of correlation $(\mathrm{R})$ between variables describing the chemical composition of the silage obtained from conventional cultivated alfalfa (control group)

\begin{tabular}{ccccccccc}
\hline Issue & $\mathrm{DM}(\%)$ & $\mathrm{CP}(\%)$ & $\mathrm{CA}(\%)$ & $\mathrm{ADF}(\%)$ & $\mathrm{NDF}(\%)$ & $\mathrm{TVFA}(\%)$ & $\mathrm{pH}$ & $\mathrm{NH}_{3}(\%)$ \\
\hline $\mathrm{DM}(\%)$ & - & +0.915 & -0.156 & +0.429 & +0.756 & +0.051 & -0.136 & -0.617 \\
$\mathrm{CP}(\%)$ & - & - & -0.114 & +0.231 & +0.932 & +0.367 & -0.177 & -0.710 \\
$\mathrm{CA}(\%)$ & - & - & - & +0.107 & -0.278 & -0.530 & -0.165 & -0.605 \\
$\mathrm{ADF}(\%)$ & - & - & - & - & -0.097 & -0.525 & +0.400 & -0.060 \\
$\mathrm{NDF}(\%)$ & - & - & - & - & - & +0.656 & -0.167 & -0.665 \\
$\mathrm{TVFA}(\%)$ & - & - & - & - & - & - & +0.197 & +0.065 \\
$\mathrm{pH}$ & - & - & - & - & - & - & - & +0.193 \\
\hline
\end{tabular}

DM - Dry Matter; CP - Crude Protein; CA - Crude Ash; ADF - Acid Detergent Fibre; NDF - Neutral Detergent Fibre; TVFA -Total Volatile Fatty Acids; NH$_{3}$ Ammonium.

Table 3. The Pearson's coefficients of correlation (R) between variables describing the chemical composition of the silage obtained from organic cultivated alfalfa (experimental group)

\begin{tabular}{ccccccccc}
\hline Issue & $\mathrm{DM}(\%)$ & $\mathrm{CP}(\%)$ & $\mathrm{CA}(\%)$ & $\mathrm{ADF}(\%)$ & $\mathrm{NDF}(\%)$ & $\mathrm{TVFA}(\%)$ & $\mathrm{pH}$ & $\mathrm{NH}_{3}(\%)$ \\
\hline $\mathrm{DM}(\%)$ & - & +0.983 & -0.250 & +0.437 & +0.653 & +0.026 & -0.074 & -0.713 \\
$\mathrm{CP}(\%)$ & - & - & -0.102 & +0.120 & +0.883 & +0.198 & -0.116 & -0.704 \\
$\mathrm{CA}(\%)$ & - & - & - & +0.572 & -0.248 & -0.681 & -0.207 & -0.704 \\
$\mathrm{AD}(\%)$ & - & - & - & - & -0.080 & -0.430 & +0.347 & -0.097 \\
$\mathrm{NDF}(\%)$ & - & - & - & - & - & +0.049 & -0.027 & -0.775 \\
$\mathrm{TVFA}(\%)$ & - & - & - & - & - & - & +0.155 & +0.029 \\
$\mathrm{pH}$ & - & - & - & - & - & - & - & +0.122 \\
\hline
\end{tabular}

DM - Dry Matter; CP - Crude Protein; CA - Crude Ash; ADF - Acid Detergent Fibre; NDF - Neutral Detergent Fibre; TVFA -Total Volatile Fatty Acids; NH 3 Ammonium.

Table 4. The total variance explained

\begin{tabular}{ccccc}
\hline Variable & Eigenvalue & \% Total variance & Cumulative - Eigenvalue & Cumulative (\%) \\
\hline Factor 1 - Organic culture & 5.988 & 37.429 & 5.988 & 37.429 \\
Factor 2 - Conventional Culture & 5.231 & 32.696 & 11.220 & 70.126 \\
\hline
\end{tabular}


Table 5. The correlations of $\mathrm{PC} 1 \times \mathrm{PC} 2$ variables (factor loadings)

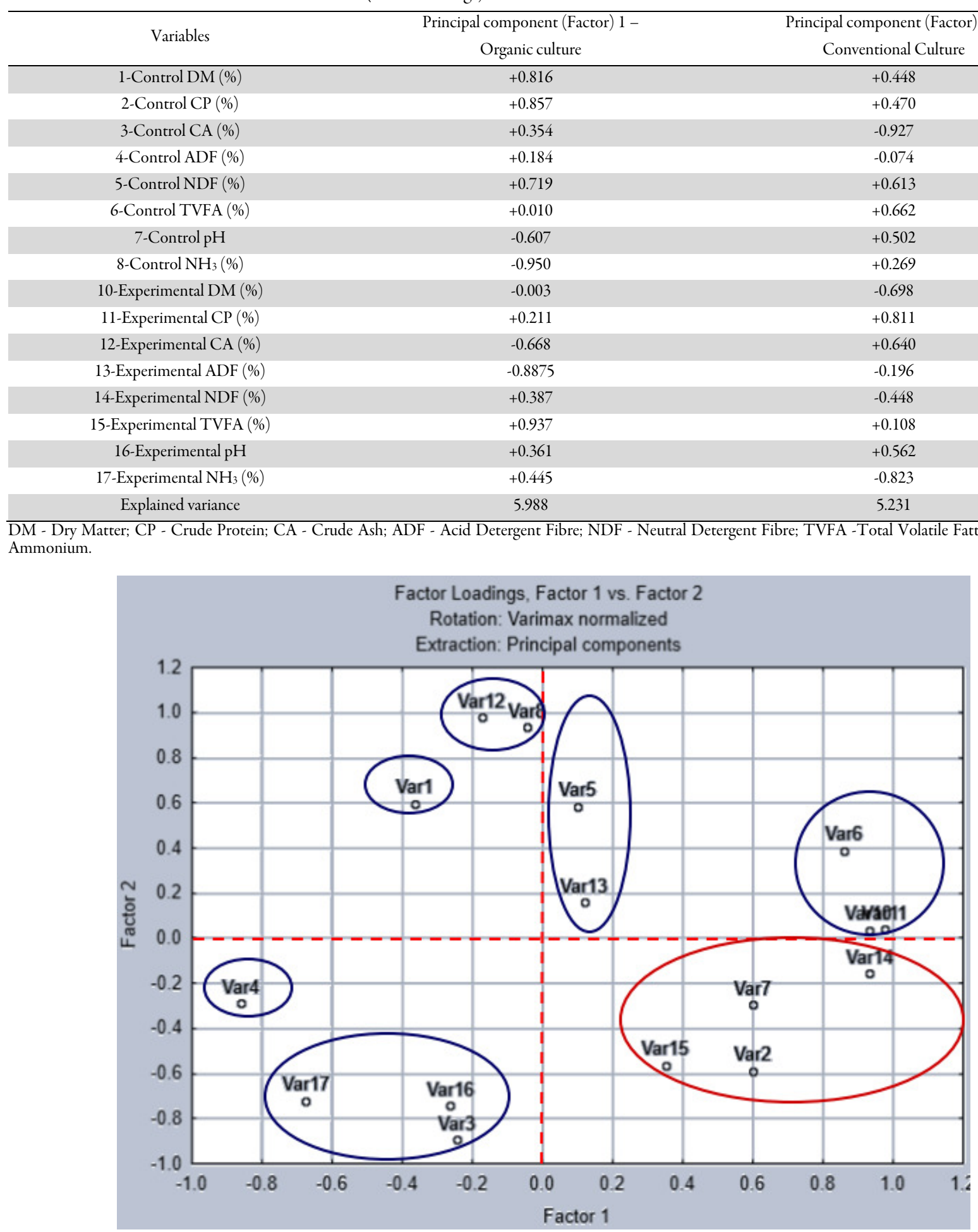

Fig. 1. Projections of the factor loadings on the PC1 $\times$ PC2 plane

Synthesizing, we can conclude that a high diversity within individual values was recorded only in ammonia content from silage obtained from alfalfa cultivated using conventional technology. In both control and experimental groups similar intensities and senses of correlations was reported between nutritional traits of the alfalfa silage, expressed through their chemical composition indices. Thus, positive very strong correlations were identified between crude protein, dry matter and neutral detergent fibre, while $\mathrm{pH}$, and ammonia were negatively correlated with majority of other analysed nutritional traits of the alfalfa silage. According to PCA, the two principal components identified explains $37.42 \%$ of variance (Factor 1 - organic culture system), and 32.69\% of variance (Factor 2 - conventional culture system). 


\section{Conclusions}

According to our study, increased amounts of crude protein, neutral detergent fibre, and total volatile fatty acids, in alfalfa silage, may be obtained when organic culture of alfalfa is practiced, while high values of crude fat and ammonia in alfalfa silage, may be obtained when alfalfa is conventionally cultivated.

\section{References}

AOAC International (2005). Official methods of analysis. 18th Association of Official Analytical Chemists, Gaithersburg, MD.

Basset-Mens C, Ledgard S, Boyes M (2009). Eco-efficiency of intensification scenarios for milk production in New Zealand. Journal of Ecology and Economy 68:1615-1625.

Dewhurst RJ, Fisher WJ, Tweed JKS, Wilkins RJ (2003). Comparison of grass and legume silages for milk production. 1. Production responses with different levels of concentrate. Journal of Dairy Science 86:25982611.

Gallo A, Moschini M, Cerioli C, Masoer F (2013). Use of principal component analysis to classify forages and predict their calculated energy content. Animal 7(6):930-939.

Hole DG, Perkins AJ, Wilson JD, Alexander IH, Grice PV, Evans AD (2005). Does organic farming benefit biodiversity? Biological Conservation 122:113-120.

Hristov AN, Price WJ, Shafii B (2004). A meta-analysis examining the relationship among dietary factors, dry matter intake, and milk and milk protein yield in dairy cows. Journal of Dairy Science 87:21842196.
Hristov AN, Price WJ, Shafii B (2002). An overview of dietary factors influencing dry matter intake and milk and milk protein yields in dairy cows. Proceedings of Pacific Northwest Animal Nutrition Conference pp 147-165.

Jenkins TC, McGuire MA (2006). Major advances in nutrition: Impact on milk composition. Journal of Dairy Science 89:1302-1310.

Larsen MK, Nielsen JH, Butle G, Leifert C, Slots T, Kristiansen GH, Gustafsson $\mathrm{AH}$ (2010). Milk quality as affected by feeding regimens in a country with dimatic variation. Journal of Dairy Science 93:2863-2873.

Leduc M, Gervais R, Tremblay GF, Chiquette J, Chouinard PY (2017). Milk fatty acid profile in cows fed red clover-or alfalfa-silage based diets differing in rumen-degradable protein supply. Animal Feed Science and Technology 233:59-72.

Norton LR, Johnson PJ, Joys AC, Stuart RC, Chamberlain DE, Feber RE, ... Fuller RJ (2009). Consequences of organic and non-organic farming practices for field, farm and landscape complexity. Agriculture, Ecosystems and Environment 129(1-3):221-227.

Stighbauer KE,Cicconi-Hogan KM, Richert R, Schukken YH, Ruegg PL, Gamroth M (2013). Assessment of herd management on organic and conventional dairy farms in the United States. Journal of Dairy Science 96:1290-1300.

Verbruggen E, Roling WFM, Gamper HA, Kowalchuk GA, VerhoefHA, van der Heijden MGA (2010). Positive effects of organic farming on below-ground mutualists: large-scale comparison of mycorrhizal fungal communities in agricultural soils. New Phytologist 186:968-979.

Wood R, Lenzen M, Dey C, Lundie S (2000). A comparative study of some environmental impacts of conventional and organic farming in Australia. Agricultural Systems 89:324348. 